\title{
Military-related sexual assault in Canada: a cross-sectional survey
}

\author{
Kimberley Watkins MA, Rachel Bennett MSc, Mark A. Zamorski MD MHSA, Isabelle Richer PhD
}

\section{Abstract}

Background: Most research on military-related sexual assault is based on the United States military and has important limitations, such as low response rates. We sought to estimate the lifetime prevalence of sexual assault, assess its relation to military service and identify the circumstances, correlates and associations with mental disorders of military-related sexual assault among Canadian military personnel.

Methods: We used the 2013 Canadian Forces Mental Health Survey, a cross-sectional representative survey of Canadian Regular Force personnel $(n=6696)$. The sample was weighted to be representative of the entire Canadian Armed Forces Regular Force population in 2012 ( $n=67776$ ), as per Statistics Canada requirements. We assessed lifetime trauma exposure and pastyear mental disorders using the Composite International Diagnostic Interview. We defined lifetime military-related sexual assault as forced sexual activity or unwanted sexual touching that occurred on deployment or in another military workplace, or was perpetrated by Department of National Defence or Canadian Armed Forces personnel. We defined all other sexual assault as non-militaryrelated sexual assault.

Results: Self-reported sexual assault was more prevalent among women (non-military-related sexual assault $24.2 \%$, military-related sexual assault $15.5 \%$ ) than men (5.9\% and $0.8 \%$, respectively). About a quarter of women with military-related sexual assault reported experiencing at least 1 event on deployment. After covariates were controlled for, military-related sexual assault was independently associated with any lifetime and any past-year mental disorder (adjusted odds ratio 2.9 and 3.0, respectively) and lifetime and past-year posttraumatic stress disorder (adjusted odds ratio 4.3 and 4.1, respectively).

Interpretation: Canadian military women are at increased risk for sexual assault and military-related sexual assault relative to their male counterparts. Deployment may be a period of elevated risk for military-related sexual assault, and women who reported militaryrelated sexual assault are more likely to have experienced mental disorders, especially posttraumatic stress disorder.

exual assault contributes substantially to the burden of mental disorders, such as posttraumatic stress disorder (PTSD), ${ }^{1}$ and may be particularly prevalent among military personnel. The military population consists largely of younger people, a group at risk for sexual assault. ${ }^{2-4}$ Military members also often live in isolated, close quarters with one another, ${ }^{3,5}$ with men greatly outnumbering and frequently outranking women. ${ }^{3,6}$ Furthermore, some aspects unique to military-related sexual assault, such as the feelings of betrayal and continuous exposure to the perpetrator when he or she is a member of the same unit, may have a disproportionate influence on mental health..$^{2,4,7,8}$

Most research on military-related sexual assault is based on the US military ${ }^{2-4,7,9}$ and has substantial limitations, such as low response rates. ${ }^{10}$ It may not, therefore, be generalizable to the Canadian military. Cotter ${ }^{11}$ found lifetime military-related sexual assault rates of $27.3 \%$ and $3.8 \%$ among Canadian mili- tary women and men, respectively. However, the study had important limitations, including its census design, and the results may not have been representative of the Canadian military as a whole.

To address these limitations and to gain a more accurate and extensive understanding of military-related sexual assault in Canada, we investigated the prevalence, circumstances, correlates

Competing interests: The authors are employed by the Department of National Defence. No other competing interests were declared.

This article has been peer reviewed.

Correspondence to: Kimberley Watkins, Kimberley.Watkins@forces. gc.ca

CMAJ Open 2017. DOI:10.9778/cmajo.20160140 
and associations with mental disorders of lifetime military- and non-military-related sexual assault, beyond the effects of other lifetime trauma, in a representative sample of Canadian military personnel.

\section{Methods}

\section{Data source and study population}

The data source was the Canadian Forces Mental Health Survey, conducted by Statistics Canada between April and August $2013 .{ }^{12}$ This survey contains a range of measures of mental health and its correlates. For the present analysis, the target population was the entire Canadian Regular Force in service when the survey frame was struck, in September 2012.

\section{Sampling and data collection}

The Canadian Forces Mental Health Survey used a stratified random sampling framework to ensure the representativeness of the sample relative to the Canadian military as a whole. Interviews were conducted face-to-face by Statistics Canada personnel using a computer-assisted personal interview.

\section{Measures}

We assessed lifetime and past-year prevalence of mental disorders (an aggregate variable of major depression, PTSD, generalized anxiety disorder or panic disorder) using the World Health Organization World Mental Health Composite International Diagnostic Interview, ${ }^{13}$ a widely used, validated tool for assessing mental disorders. We used 4 outcomes to capture a range of current and past mental disorders that may be associated with sexual trauma: lifetime and pastyear PTSD, and any lifetime and past-year mood or anxiety disorder.

We assessed lifetime exposure to nonsexual trauma with a sum score of a 26-item inventory of nonsexual potentially traumatic experiences of the Composite International Diagnostic Interview PTSD module. Higher scores indicate greater lifetime exposure to nonsexual trauma.

We measured lifetime sexual assault using the 2 items related to sexual trauma of the Composite International Diagnostic Interview PTSD module trauma inventory: forced sexual activity ("We define sexual assault as anyone forcing you or attempting to force you into any unwanted sexual activity, by threatening you, holding you down or hurting you in some way. Has this ever happened to you?") and unwanted sexual touching ("Has anyone ever touched you against your will in any sexual way? By this I mean unwanted touching or grabbing, to kissing or fondling"). An affirmative response to either or both of these questions constituted lifetime sexual assault.

Respondents who replied "Yes" to either sexual assault item were asked 3 follow-up questions: "Did this ever take place while deployed on a Canadian Forces operation?", "Did this ever take place in your Canadian Forces workplace (other than on deployment)?" and "Were any of the persons who committed this or these acts a Canadian Forces member or civilian Department of National Defence employee at the time of this or these events?" We classified these participants into 2 mutually exclusive groups based on their responses to these questions: participants who responded affirmatively to any of the 3 questions (for forced sexual activity and/or unwanted touching) were categorized as having experienced military-related sexual assault, and the remaining participants were classified as having experienced lifetime non-militaryrelated sexual assault. Participants who did not report any lifetime sexual assault based on the initial questions were classified into a third mutually exclusive group labelled "No lifetime sexual assault."

The survey also assessed sociodemographic and military characteristics at the time of the interview, including age group, race, marital status, geographic region of the participant's military base, rank category, military element and history of deployment.

\section{Statistical analysis}

We used SPSS version 20 (IBM) and Stata version 13 (StataCorp) for the analyses; all results are weighted. By adjusting for initial sampling weights, outlying cases and participant nonresponse, Statistics Canada enabled the sample to be representative of the entire Canadian Armed Forces Regular Force population in $2012(n=67776) .^{12,14} \mathrm{We}$ estimated standard errors using linearization or bootstrap methods. Risk factors for military-related sexual assault and non-militaryrelated sexual assault were identified with multinomial logistic regression. Covariates with an unadjusted association with the outcomes were included in the adjusted model. We restricted this analysis to women because of low event rates in men.

We assessed the adjusted and unadjusted associations between lifetime non-military-related sexual assault and military-related sexual assault and mental health outcomes (in women only) using 4 binary logistic regression models, 1 per outcome (lifetime PTSD, past-year PTSD, any lifetime mood or anxiety disorder, and any past-year mood or anxiety disorder). To compare models, we included the same covariates in all 4 models (specifically, those with an unadjusted relation with any of the outcomes).

The primary variable of lifetime sexual assault category was missing in cases representing less than $0.2 \%$ of the overall population. We used listwise deletion for missing values in the regression models, resulting in elimination of cases representing $2.5 \%-3.8 \%$ of the population in each model.

\section{Ethics approval}

The data collection and data access procedures for the survey were reviewed and approved by the relevant policy committees at Statistics Canada that fulfill the functions of a Research Ethics Board, following the principles of the Tri-Council Policy Statement: Ethical Conduct of Research Involving Humans, if necessary.

\section{Results}

Of the 8393 Regular Force members invited, 6696 participated, for a response rate of $79.8 \%$ (Table 1). The results of 


\section{OPEN}

the survey presented are weighted to the entire Canadian Regular Force in September $2012(n=64280)$, as per Statistics Canada requirements.

Of the 64280 participants in the weighted survey, 7280 $(11.3 \%)$ reported any lifetime sexual assault, which was more common among women (3540 [39.8\%]) than men (3720 [6.7\%]) (Table 2). The overall prevalence of lifetime non-military-related sexual assault was 8.5\% (5440/64 280), with a higher proportion of women reporting it than men $(24.2 \%$ [2160/8900] v. $5.9 \%$ [3260/55 360]). Fewer participants (1840 [2.9\%]) reported military-related sexual assault, which was also more prevalent among female (460 [15.5\%]) than male (1380 [0.8\%]) members. Sexual touching was more prevalent than forced sexual activity among both women and men.

More than a quarter $(27.5 \%)$ of women with militaryrelated sexual assault reported that at least 1 instance had occurred on deployment (Table 3). More than half (58.7\%) of the participants with military-related sexual assault stated that at least 1 event had occurred in a Canadian military workplace other than on deployment. Most participants (91.3\%) who had experienced military-related sexual assault reported that it had been committed by a Canadian military member or a civilian Department of National Defence employee.

Risk factors for sexual assault are given in Table 4 and Table 5. In the final model (Table 5), being single (never married), living in the Western region, being a senior noncommissioned member or officer (all at the time of the survey) and having experienced more lifetime nonsexual traumatic events were independently associated with military-related sexual assault. Deployment had an association with military-related sexual assault in the unadjusted analysis that neutralized in the final model. Only being aged 40 years or more at the time of the survey and having experienced more lifetime nonsexual traumatic events were independently associated with nonmilitary-related sexual assault.

Table 6 summarizes the associations between sexual assault category and mental health outcomes; detailed results are shown in Table 7, Table 8, Table 9 and Table 10. Four in 10 women $(39.7 \%)$ with military-related sexual assault had had PTSD in their lifetime, and almost a quarter (23.5\%) had pastyear PTSD. After potentially confounding variables were controlled for, women who had experienced military-related sexual assault were about 3 times as likely as those with no sexual assault to have had any lifetime and any past-year mood or anxiety disorder, and about 4 times as likely to have had lifetime or past-year PTSD. Non-military-related sexual assault showed weaker and less consistent associations with the outcomes, although the odds ratios for military-related sexual assault and non-military-related sexual assault did not differ significantly.

\section{Interpretation}

In this representative sample of Canadian military members, lifetime sexual assault was reported more commonly by women than by men, at rates of $24.2 \%$ and $5.9 \%$, respectively, for non-military-related sexual assault and $15.5 \%$ and $0.8 \%$, respectively, for military-related sexual assault. Most incidents of sexual assault were unwanted sexual touching. Most cases of military-related sexual assault had been perpetrated by military or civilian Department of National Defence personnel and had

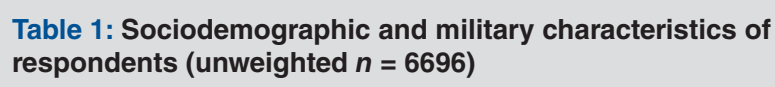

\begin{tabular}{cc}
\hline & Weighted no. ${ }^{*} \dagger(\%)$ of \\
Characteristic & respondents
\end{tabular}

\begin{tabular}{|lcc|}
\hline Sex & & \\
\hline Male & $55480(86.2)$ & $85.3-87.0$ \\
\hline Female & $8920(13.9)$ & $13.0-14.7$ \\
\hline Age group, yr & & \\
\hline $17-24$ & $8560(13.3)$ & $12.4-14.2$ \\
\hline $25-29$ & $12640(19.6)$ & $18.6-20.7$ \\
\hline $30-34$ & $11580(18.0)$ & $17.0-19.0$ \\
\hline $35-39$ & $9220(14.3)$ & $13.4-15.3$ \\
\hline $40-44$ & $8640(13.4)$ & $12.6-14.2$ \\
\hline $45-49$ & $7820(12.1)$ & $11.4-12.9$ \\
\hline $50-69$ & $7820(9.2)$ & $8.5-9.9$
\end{tabular}

\begin{tabular}{|lcc|}
\hline Ethnicity & & \\
\hline White & $57900(90.1)$ & $89.3-90.9$ \\
\hline Other & $6360(9.9)$ & $9.1-0.7$ \\
\hline Marital status & $17300(26.9)$ & $25.8-28.0$ \\
\hline Single (never married) & $42200(65.6)$ & $64.5-66.7$ \\
\hline Married/common-law & $4840(7.5)$ & $6.9-8.2$ \\
\hline $\begin{array}{l}\text { Widowed/divorced/ } \\
\text { separated }\end{array}$ & &
\end{tabular}

\begin{tabular}{|c|c|c|}
\hline \multicolumn{3}{|l|}{ Region } \\
\hline Atlantic & $14480(22.5)$ & $21.5-23.5$ \\
\hline Quebec & $9740(15.1)$ & $14.3-16.0$ \\
\hline Central/Ontario & 23660 (36.7) & $35.5-38.0$ \\
\hline Western & $16540(25.7)$ & $24.5-26.8$ \\
\hline \multicolumn{3}{|l|}{ Rank categorył } \\
\hline $\begin{array}{l}\text { Junior noncommissioned } \\
\text { member }\end{array}$ & $35440(55.0)$ & $54.8-55.2$ \\
\hline $\begin{array}{l}\text { Senior noncomissioned } \\
\text { member }\end{array}$ & $15500(24.1)$ & $23.8-24.3$ \\
\hline Officer & 13460 (20.9) & $20.8-21.0$ \\
\hline \multicolumn{3}{|l|}{ Element } \\
\hline Army & $34220(53.1)$ & $51.9-54.3$ \\
\hline Navy & $11100(17.2)$ & $16.3-18.2$ \\
\hline Air Force & $19100(29.7)$ & $28.6-30.8$ \\
\hline \multicolumn{3}{|l|}{ Ever deployed } \\
\hline No & 24780 (38.5) & $37.6-39.4$ \\
\hline \multicolumn{3}{|l|}{ Yes } \\
\hline \multicolumn{3}{|c|}{$\begin{array}{l}\text { Note: } \mathrm{Cl}=\text { confidence interval. } \\
\text { *Weighted to the entire Canadian Regular Force in service in September } 2012 \text {. } \\
\text { To protect the identity of respondents, Statistics Canada permits the release only } \\
\text { of weighted cell counts, which must be rounded to the nearest } 20 \text {. We calculated } \\
\text { prevalence rates using these rounded cell counts. } \\
\text { Totals may not add up owing to rounding. } \\
\text { fJunior noncommissioned member includes the ranks of Master Corporal/ } \\
\text { Master Seaman and below; senior noncommissioned member includes the } \\
\text { ranks of Sergeant/Petty Officer 2nd class and above. }\end{array}$} \\
\hline
\end{tabular}


Table 2: Prevalence of lifetime sexual assault by sex ${ }^{\star}$

\begin{tabular}{|c|c|c|c|}
\hline \multirow[b]{2}{*}{ Sexual assault category } & \multicolumn{3}{|c|}{ Weighted no.†‡ (\%) of participants $(95 \% \mathrm{Cl})$} \\
\hline & $\begin{array}{c}\text { Men } \\
n=55380\end{array}$ & $\begin{array}{l}\text { Women } \\
n=8900\end{array}$ & $\begin{array}{c}\text { Total } \\
n=64280\end{array}$ \\
\hline No lifetime sexual assault & 51640 (93.3) (92.6-94.0) & $5360(60.1)(56.8-63.3)$ & $57000(88.7)(87.9-89.5)$ \\
\hline \multicolumn{4}{|c|}{$\begin{array}{l}\text { Lifetime non-military-related } \\
\text { sexual assault }\end{array}$} \\
\hline Forced sexual activity & $-\S$ & $-\S$ & $-\S$ \\
\hline Unwanted sexual touching & $3120(5.6)(5.0-6.3)$ & $2120(23.8)(20.9-26.6)$ & $5240(8.2)(7.5-8.8)$ \\
\hline Any sexual assaultๆ & $3260(5.9)(5.2-6.5)$ & $2160(24.2)(21.3-27.1)$ & $5420(8.4)(7.8-9.2)$ \\
\hline \multicolumn{4}{|c|}{$\begin{array}{l}\text { Lifetime military-related sexual } \\
\text { assault }{ }^{\star *}\end{array}$} \\
\hline Forced sexual activity & $100(0.2)(0.1-0.3)$ & $680(7.6)(5.9-9.5)$ & $780(1.2)(1.0-1.5)$ \\
\hline Unwanted sexual touching & $420(0.8)(0.5-1.0)$ & $1320(14.8)(12.5-17.1)$ & $1740(2.7)(2.3-3.1)$ \\
\hline Any sexual assaultๆ & $460(0.8)(0.6-1.1)$ & $1380(15.5)(13.1-17.8)$ & $1840(2.9)(2.5-3.3)$ \\
\hline \multicolumn{4}{|c|}{$\begin{array}{l}\text { Note: } \mathrm{Cl}=\text { confidence interval. } \\
{ }^{*} \text { Cases representing } 0.19 \% \text { of the population were excluded because of missing values. } \\
\text { †Weighted to the entire Canadian Regular Force in service in September 2012. To protect the identity of respondents, Statistics Canada permits the } \\
\text { release only of weighted cell counts, which must be rounded to the nearest } 20 \text {. We calculated prevalence rates using these rounded cell counts. } \\
\text { †Totals may not add up owing to rounding. } \\
\text { §These values are suppressed owing to Statistics Canada's guidelines for vetting of output. Although the cell sizes were above the prescribed minimum } \\
\text { for this survey (unweighted } n \geq 5 \text { ), earlier versions of the table released with minimally recoded variables had results that differed from these results by } \\
\text { less than the minimum cell requirement and hence could not be released. } \\
\text { ๆlncludes forced sexual activity and unwanted sexual touching, which are not mutually exclusive. } \\
{ }^{*} \text { With or without lifetime non-military-related sexual assault. }\end{array}$} \\
\hline
\end{tabular}

Table 3: Context of military-related sexual assault by sex

\begin{tabular}{|c|c|c|c|}
\hline \multirow[b]{2}{*}{ Type of sexual assault; context } & \multicolumn{3}{|c|}{ Weighted no. ${ }^{*}(\%)$ of participants $(95 \% \mathrm{Cl})$} \\
\hline & $\begin{array}{c}\text { Men } \\
n=460\end{array}$ & $\begin{array}{l}\text { Women } \\
n=1380\end{array}$ & $\begin{array}{c}\text { Total } \\
n=1840\end{array}$ \\
\hline \multicolumn{4}{|l|}{ Forced sexual activity } \\
\hline While deployed on CAF mission & $-\dagger$ & 160 (23.5) (12.7-34.3) & $-\dagger$ \\
\hline $\begin{array}{l}\text { Occurred in CAF workplace (other } \\
\text { than deployment) }\end{array}$ & $-\dagger$ & $420(61.8)(49.6-74.0)$ & $-\dagger$ \\
\hline $\begin{array}{l}\text { Committed by CAF member or } \\
\text { civilian DND employee }\end{array}$ & $80(80.0)(51.8-100.0)$ & $620(91.2)(84.5-97.9)$ & 700 (89.7) (82.6-96.8) \\
\hline Any forced sexual activity $\ddagger$ & 100 & 680 & 780 \\
\hline \multicolumn{4}{|l|}{ Unwanted sexual touching } \\
\hline While deployed on CAF mission & $-\dagger$ & $360(27.3)(19.5-35.0)$ & $-†$ \\
\hline $\begin{array}{l}\text { Occurred in CAF workplace (other } \\
\text { than deployment) }\end{array}$ & $260(61.9)(46.6-77.2)$ & $780(59.1)(50.4-67.8)$ & $1040(59.8)(52.2-67.4)$ \\
\hline $\begin{array}{l}\text { Committed by CAF member or } \\
\text { civilian DND employee }\end{array}$ & 380 (90.5) (79.7-100) & 1240 (93.9) (90.6-97.3) & $1620(93.1)(89.2-97.0)$ \\
\hline Any unwanted sexual touching $\ddagger$ & 420 & 1320 & 1740 \\
\hline \multicolumn{4}{|l|}{ Any sexual assault } \\
\hline While deployed on CAF mission & $60(13.0)(2.4-23.7)$ & $380(27.5)(20.0-35.1)$ & 440 (23.9) (17.6-30.3) \\
\hline $\begin{array}{l}\text { Occurred in CAF workplace (other } \\
\text { than deployment) }\end{array}$ & $260(56.5)(41.4-71.6)$ & $820(59.4)(51.0-67.8)$ & $1080(58.7)(51.3-66.1)$ \\
\hline $\begin{array}{l}\text { Committed by CAF member or } \\
\text { civilian DND employee }\end{array}$ & 380 (82.6) (70.9-94.3) & 1300 (94.2) (90.5-97.9) & 1680 (91.3) (87.2-95.4) \\
\hline Any sexual assault $\ddagger$ & 460 & 1380 & 1840 \\
\hline \multicolumn{4}{|c|}{$\begin{array}{l}\text { Note: } \mathrm{Cl}=\text { confidence interval, } \mathrm{CAF}=\text { Canadian Armed Forces, DND = Department of National Defence. } \\
\text { *Weighted to the entire Canadian Regular Force in service in September 2012. To protect the identity of respondents, Statistics Canada permits the } \\
\text { release only of weighted cell counts, which must be rounded to the nearest } 20 . \text { We calculated prevalence rates using these rounded cell counts. } \\
\text { †Insufficient data for presentation (does not meet Statistics Canada's minimum cell count requirements). } \\
\text { fThis does not reflect the sum of the contexts, as the categories are not mutually exclusive. }\end{array}$} \\
\hline
\end{tabular}




\section{OPEN}

Research

occurred in a workplace other than on deployment. Deployment was associated with military-related sexual assault only in the unadjusted findings. Military-related sexual assault was associated with a greater number of lifetime nonsexual traumatic events as well as an increased risk of both lifetime and past-year mental disorders and PTSD.
The lifetime military-related sexual assault rates of $15.5 \%$ among women and $0.8 \%$ among men that we found are lower than the rates of $27.3 \%$ and $3.8 \%$, respectively, that Cotter ${ }^{11}$ recently found among Canadian military personnel. His study, however, focused exclusively on sexual misconduct. The use of a census framework and response rate of $61 \%$ sug-

Table 4: Lifetime sexual assault category by sociodemographic and military risk factors, among women*

Weighted no.†‡ (\%) of participants $(95 \% \mathrm{Cl}) \S$

$n=8900$

\begin{tabular}{|c|c|c|c|c|}
\hline Risk factor & No lifetime sexual assault & $\begin{array}{l}\text { Lifetime non-military- } \\
\text { related sexual assault }\end{array}$ & $\begin{array}{l}\text { Lifetime military-related } \\
\text { sexual assault }\end{array}$ & $\begin{array}{l}\text { Total weighted } \\
\text { no.f }\end{array}$ \\
\hline \multicolumn{5}{|l|}{ Age group, yr } \\
\hline$<30$ & $1780(68.5)(62.1-74.9)$ & 460 (17.7) (12.5-22.9) & 340 (13.1) (8.3-17.9) & 2600 \\
\hline $30-39$ & 1740 (58.8) (52.8-64.7) & 760 (25.7) (20.3-31.1) & 460 (15.5) (11.5-19.6) & 2960 \\
\hline$\geq 40$ & $1840(55.1)(49.8-60.4)$ & $940(28.1)(23.2-33.1)$ & $580(17.4)(13.5-21.2)$ & 3340 \\
\hline \multicolumn{5}{|l|}{ Ethnicity } \\
\hline White & 4820 (60.9) (57.3-64.4) & 1860 (23.5) (20.3-26.6) & 1240 (15.7) (13.1-18.2) & 7920 \\
\hline Other & $540(55.1)(44.1-66.1)$ & $300(30.6)(20.3-41.0)$ & $140(14.3)(7.0-21.6)$ & 980 \\
\hline \multicolumn{5}{|l|}{ Marital status } \\
\hline Single (never married) & 1220 (53.0) (46.5-60.5) & 560 (24.6) (18.4-30.8) & 520 (22.8) (16.9-28.7) & 2280 \\
\hline Married/common-law & 3420 (62.0) (57.8-66.1) & 1340 (24.4) (20.5-28.0) & $760(13.8)(11.1-16.6)$ & 5500 \\
\hline Widowed/divorced/separated & 720 (64.3) (54.4-74.2) & $260(23.2)(14.1-32.4)$ & $120(10.7)(4.9-16.5)$ & 1120 \\
\hline \multicolumn{5}{|l|}{ Region } \\
\hline Atlantic & 1060 (65.4) (58.0-72.8) & 380 (23.5) (16.9-30.0) & $180(11.1)(6.3-15.9)$ & 1620 \\
\hline Quebec & 780 (65.0) (55.9-74.1) & $280(23.3)(15.3-31.3)$ & $140(11.7)(5.2-18.1)$ & 1200 \\
\hline Central/Ontario & 2380 (61.3) (56.2-66.5) & 960 (24.7) (20.1-29.4) & 540 (13.9) (10.5-17.3) & 3880 \\
\hline Western & 1160 (52.3) (45.2-59.3) & 540 (24.3) (18.0-30.6) & 520 (23.4) (17.6-29.3) & 2220 \\
\hline \multicolumn{5}{|l|}{ Rank category } \\
\hline $\begin{array}{l}\text { Junior noncommissioned } \\
\text { member }\end{array}$ & 2760 (59.5) (54.2-64.8) & $1320(28.4)(23.5-33.4)$ & $580(12.5)(9.0-16.0)$ & 4640 \\
\hline $\begin{array}{l}\text { Senior noncommissioned } \\
\text { member }\end{array}$ & $1180(58.4)(52.4-64.4)$ & $420(20.8)(15.9-25.7)$ & $420(20.8)(15.9-25.7)$ & 2020 \\
\hline Officer & 1440 (63.7) (58.3-69.2) & 440 (19.5) (15.1-23.9) & 380 (16.8) (12.5-21.1) & 2260 \\
\hline \multicolumn{5}{|l|}{ Element } \\
\hline Army & $2400(60.0)(54.9-65.1)$ & 1000 (25.0) (20.4-29.6) & $620(15.5)(11.8-19.2)$ & 4000 \\
\hline Navy & 940 (60.3) (52.6-68.0) & $320(20.5)(14.3-26.7)$ & 300 (19.2) (13.0-25.5) & 1560 \\
\hline Air Force & $2040(61.1)(55.5-66.6)$ & 860 (25.7) (20.6-30.9) & $460(13.8)(10.1-17.4)$ & 3340 \\
\hline \multicolumn{5}{|l|}{ Ever deployed } \\
\hline No & 2860 (64.4) (59.3-69.5) & 1040 (23.4) (18.8-28.0) & $540(12.2)(8.8-15.5)$ & 4440 \\
\hline Yes & $2500(56.1)(51.6-60.5)$ & 1140 (25.6) (21.7-29.5) & 840 (18.8) (15.3-22.3) & 4460 \\
\hline $\begin{array}{l}\text { No. of types of lifetime } \\
\text { nonsexual trauma, mean } \\
(95 \% \mathrm{Cl})\end{array}$ & $2.10(1.91-2.29)$ & 3.96 (3.55-4.37) & $4.90(4.32-5.45)$ & $2.99(2.80-3.18)$ \\
\hline \multicolumn{5}{|c|}{$\begin{array}{l}\text { Note: } \mathrm{Cl}=\text { confidence interval. } \\
{ }^{*} \text { Cases representing } 0.2 \% \text { of the population were excluded because of missing values. } \\
\text { tWeighted to the entire Canadian Regular Force in service in September 2012. To protect the identity of respondents, Statistics Canada permits the release only of } \\
\text { weighted cell counts, which must be rounded to the nearest } 20 \text {. We calculated prevalence rates using these rounded cell counts. } \\
\text { fTotals may not add up owing to rounding. } \\
\text { §Except where noted otherwise. }\end{array}$} \\
\hline
\end{tabular}


gest potential selection bias, such that members who had experienced sexual assault may have been more likely to respond than members who had not experienced sexual assault. Cotter used an online survey, and the greater per- ceived anonymity may have increased reporting. In his definition of military-related sexual assault, Cotter included, in addition to forced sexual activity and unwanted sexual touching, an item assessing sexual activity without consent. With

\begin{tabular}{|c|c|c|c|c|}
\hline \multirow[b]{3}{*}{ Characteristic } & \multicolumn{4}{|c|}{$\begin{array}{l}\text { Relative risk ratio }(95 \% \mathrm{Cl}) \ddagger \\
\quad \text { Weighted } n=8900 \S\end{array}$} \\
\hline & \multicolumn{2}{|c|}{ Unadjusted } & \multicolumn{2}{|c|}{ Adjusted } \\
\hline & $\begin{array}{l}\text { Lifetime non-military- } \\
\text { related sexual assault } \\
\text { v. no sexual assault }\end{array}$ & $\begin{array}{l}\text { Lifetime military- } \\
\text { related sexual assault } \\
\text { v. no sexual assault }\end{array}$ & $\begin{array}{l}\text { Lifetime non-military- } \\
\text { related sexual assault } \\
\text { v. no sexual assault }\end{array}$ & $\begin{array}{l}\text { Lifetime military- } \\
\text { related sexual assault } \\
\text { v. no sexual assault }\end{array}$ \\
\hline \multicolumn{5}{|l|}{ Age group, yr } \\
\hline$<30$ & Reference & Reference & Reference & Reference \\
\hline $30-39$ & $1.66(1.05-2.62)$ & $1.36(0.80-2.31)$ & $1.62(0.98-2.66)$ & $1.22(0.67-2.23)$ \\
\hline$\geq 40 \mathrm{yr}$ & $1.93(1.22-3.05)$ & $1.64(0.98-2.74)$ & $2.10(1.20-3.67)$ & $1.44(0.79-2.65)$ \\
\hline \multicolumn{5}{|l|}{ Ethnicity } \\
\hline White & Reference & Reference & $-\eta$ & $-\eta$ \\
\hline Other & $1.44(0.84-2.49)$ & $1.06(0.54-2.11)$ & $-\eta$ & $-\eta$ \\
\hline \multicolumn{5}{|l|}{ Marital status } \\
\hline Single (never married) & $1.19(0.79-1.81)$ & $1.91(1.24-2.94)$ & $1.57(0.98-2.52)$ & $2.58(1.56-4.25)$ \\
\hline Married/common-law & Reference & Reference & Reference & Reference \\
\hline Widowed/divorced/separated & $0.93(0.52-1.66)$ & $0.78(0.39-1.56)$ & $0.73(0.38-1.41)$ & $0.62(0.29-1.35)$ \\
\hline \multicolumn{5}{|l|}{ Region } \\
\hline Atlantic & $0.90(0.55-1.46)$ & $0.77(0.43-1.40)$ & $0.97(0.57-1.64)$ & $1.01(0.52-1.97)$ \\
\hline Quebec & $0.89(0.51-1.57)$ & $0.84(0.41-1.72)$ & $0.87(0.48-1.57)$ & $1.02(0.48-2.14)$ \\
\hline Ontario & Reference & Reference & Reference & Reference \\
\hline Western & $1.16(0.74-1.83)$ & $1.97(1.27-3.07)$ & $1.16(0.71-1.88)$ & $2.34(1.47-3.72)$ \\
\hline \multicolumn{5}{|l|}{ Rank category } \\
\hline $\begin{array}{l}\text { Junior noncommissioned } \\
\text { member }\end{array}$ & Reference & Reference & Reference & Reference \\
\hline $\begin{array}{l}\text { Senior noncommissioned } \\
\text { member }\end{array}$ & $0.75(0.49-1.14)$ & $1.76(1.11-2.78)$ & $0.64(0.39-1.06)$ & $1.93(1.11-3.35)$ \\
\hline Officer & $0.64(0.44-0.93)$ & $1.29(0.81-2.06)$ & $0.75(0.49-1.14)$ & $2.05(1.21-3.45)$ \\
\hline \multicolumn{5}{|l|}{ Element } \\
\hline Army & Reference & Reference & $-\eta$ & $-\eta$ \\
\hline Navy & $0.81(0.51-1.30)$ & $1.28(0.78-2.10)$ & $-\eta$ & $-\eta$ \\
\hline Air Force & $1.00(0.68-1.48)$ & $0.87(0.55-1.38)$ & $-\eta$ & -9 \\
\hline \multicolumn{5}{|l|}{ Ever deployed } \\
\hline No & Reference & Reference & Reference & Reference \\
\hline Yes & $1.25(0.88-1.78)$ & $1.75(1.17-2.64)$ & $0.76(0.51-1.15)$ & $0.86(0.54-1.37)$ \\
\hline $\begin{array}{l}\text { Count of types of lifetime } \\
\text { nonsexual trauma }\end{array}$ & $1.33(1.24-1.44)$ & $1.46(1.34-1.60)$ & $1.34(1.23-1.45)$ & $1.51(1.37-1.66)$ \\
\hline \multicolumn{5}{|c|}{$\begin{array}{l}\text { Note: } \mathrm{Cl}=\text { confidence interval. } \\
\text { *Multinomial logistic regression. } \\
\text { †Cases representing } 0.2 \% \text { of the population were excluded because of missing values. } \\
\text { fResults are presented as relative risk ratios as opposed to odds ratios so as to provide more comparable estimates of effect size across covariates and outcomes. } \\
\text { \$Weighted to the entire Canadian Regular Force in service in September 2012. To protect the identity of respondents, Statistics Canada permits the release only of } \\
\text { weighted cell counts, which must be rounded to the nearest } 20 \text {. We calculated prevalence rates using these rounded cell counts. } \\
\text { qNot included in final model owing to the lack of an unadjusted association with the outcome. }\end{array}$} \\
\hline
\end{tabular}


rates of $8.7 \%$ and $0.7 \%$ among women and men, respectively, this third experience may have contributed to the increased overall prevalence in Cotter's study.

The rates of lifetime sexual assault that we found did not differ substantially from those reported in a study in the Canadian general population that used the same items as we did (forced sexual activity and unwanted sexual touching). ${ }^{1}$ Although comparing rates of military-related sexual assault across studies is complicated by methodological differences, ${ }^{2,3,7,9,15}$ the prevalence rates we observed are slightly lower than those reported in a meta-analysis of primarily USbased research (23.6\% for women and $1.9 \%$ for men). ${ }^{15}$

Previous research has shown deployment, especially with combat, to be a period of risk for military-related sexual assault, ${ }^{16,17}$ owing to factors such as lengthy periods without permitted sexual activity and close living quarters combining men with relatively few women. ${ }^{6} \mathrm{We}$ did not find an elevated adjusted risk of military-related sexual assault among women who had been deployed in the past. However, this null finding was likely due to differences in incidence- and prevalenceoriented measures in the context of multiple potential military-related sexual assault events. ${ }^{18}$ More than a quarter of women with military-related sexual assault reported that at least 1 event had occurred on deployment, despite the relatively short time military personnel spend deployed. This finding indicates that military-related sexual assault may be more likely to occur on deployment.

Also consistent with past research, military-related sexual assault was associated with an increased likelihood of having a mental disorder, particularly PTSD. The odds of these mental disorders did not differ significantly between women who reported military-related sexual assault and non-militaryrelated sexual assault. However, the odds were higher among women with military-related sexual assault, which is in line with previous findings that military-related sexual assault may be more psychologically harmful than non-military-related sexual assault. $2,4,7,8$

\section{Limitations}

Some limitations of our study must be considered. The data were self-reported and were collected in face-to-face interviews, which is associated with variability in reporting of assault. ${ }^{9}$ The study was cross-sectional, so we could not determine the direction of the association between sexual assault and mental disorders. Because the survey assessed only the prevalence and not the incidence of sexual assault, we could not examine cumulative effects of sexual assault on mental health. We also could not determine, among those with military-related sexual assault, how much, if any, nonmilitary-related sexual assault they had experienced, which is especially important given the role that prior sexual assault may play in subsequent assault. ${ }^{19,20}$ Moreover, because the sociodemographic information was collected at the time of the interview, we could not determine whether variables such as marital status or region were risk factors for militaryrelated sexual assault at the time of occurrence. Finally, the low prevalence of military-related sexual assault among men precluded any analysis of its risk factors or associations with

\begin{tabular}{|c|c|c|c|c|}
\hline \multirow[b]{2}{*}{ Variable } & \multicolumn{4}{|c|}{$\begin{array}{l}\text { Mental health outcome; weighted no.§ (\%) of participants }(95 \% \mathrm{Cl}) \\
\qquad n=8580-8700\end{array}$} \\
\hline & $\begin{array}{l}\text { Any lifetime mood or } \\
\text { anxiety disorder }\end{array}$ & $\begin{array}{l}\text { Any past-year mood or } \\
\text { anxiety disorder }\end{array}$ & Lifetime PTSD & Past-year PTSD \\
\hline Overall & 3620 (41.9) (38.5-45.3) & 1760 (20.5) (17.6-23.4) & 1640 (18.9) (16.0-21.8) & 760 (8.7) (6.6-10.9) \\
\hline No lifetime sexual assault & $1580(30.3)(26.4-34.1)$ & 700 (13.5) (10.4-16.6) & $420(8.0)(5.5-10.4)$ & 200 (3.8) (2.1-5.5) \\
\hline $\begin{array}{l}\text { Lifetime non-military-related } \\
\text { sexual assault }\end{array}$ & $1120(54.9)(47.1-62.7)$ & $500(24.8)(18.5-31.0)$ & 660 (32.7) (25.6-39.7) & $240(11.7)(6.6-16.7)$ \\
\hline \multirow[t]{2}{*}{ Military-related sexual assault } & 900 (66.2) (58.0-74.3) & 560 (41.2) (32.7-49.6) & 540 (39.7) (31.1-48.3) & $320(23.5)(16.2-30.9)$ \\
\hline & \multicolumn{4}{|c|}{ Adjusted ORף (95\% Cl) } \\
\hline $\begin{array}{l}\text { Lifetime non-military-related } \\
\text { sexual assault v. no lifetime } \\
\text { sexual assault }\end{array}$ & $1.87(1.23-2.85)$ & $1.58(0.93-2.68)$ & $3.68(2.14-6.34)$ & $2.14(0.94-4.86)$ \\
\hline $\begin{array}{l}\text { Military-related sexual assault } \\
\text { v. no lifetime sexual assault }\end{array}$ & $2.88(1.85-4.50)$ & $3.00(1.79-5.05)$ & $4.32(2.27-8.20)$ & $4.06(1.62-10.21)$ \\
\hline \multicolumn{5}{|c|}{$\begin{array}{l}\text { Note: } \mathrm{Cl}=\text { confidence interval, } \mathrm{OR}=\text { odds ratio, } \mathrm{PTSD}=\text { posttraumatic stress disorder. } \\
\text { * } \mathrm{Summary} \text { of final binary logistic regression models. } \\
\text { †Cases representing } 2.5 \%-3.8 \% \text { of the population were excluded from the final model because of missing values. } \\
\text { †Detailed regression results are shown in Tables } 7-10 \text {. } \\
\text { \$Weighted to the entire Canadian Regular Force in service in September 2012. To protect the identity of respondents, Statistics Canada permits the release only of } \\
\text { weighted cell counts, which must be rounded to the nearest } 20 \text {. We calculated prevalence rates using these rounded cell counts. } \\
\text { ๆAdjusted for age group, marital status, region, rank category, element, deployment history and number of lifetime nonsexual traumatic events. }\end{array}$} \\
\hline
\end{tabular}


Table 7: Association of lifetime sexual assault with any lifetime mood or anxiety disorder* among women†¥

\begin{tabular}{|c|c|c|c|}
\hline Variable & $\begin{array}{l}\text { Weighted no.§ }(\%) \text { of } \\
\text { participants }(95 \% \mathrm{Cl}) \uparrow \\
n \text { in final model }=8620\end{array}$ & $\begin{array}{l}\text { Unadjusted OR } \\
\qquad(95 \% \mathrm{Cl})\end{array}$ & $\begin{array}{l}\text { Adjusted OR** } \\
\qquad(95 \% \mathrm{Cl})\end{array}$ \\
\hline \multicolumn{4}{|l|}{ Age group, yr } \\
\hline$<30$ & 820 (31.5) (25.0-38.1) & Reference & Reference \\
\hline 30-39 & 1240 (43.7) (37.6-49.7) & $1.65(1.12-2.43)$ & $1.50(0.96-2.33)$ \\
\hline$\geq 40 \mathrm{yr}$ & $1560(48.4)(43.0-53.9)$ & $2.00(1.38-2.90)$ & $1.74(1.07-2.81)$ \\
\hline \multicolumn{4}{|l|}{ Ethnicity } \\
\hline White & 3240 (42.2) (38.5-45.9) & Reference & $-† \dagger$ \\
\hline Other & $400(41.7)(30.8-52.6)$ & $0.94(0.56-1.59)$ & $-† \dagger$ \\
\hline \multicolumn{4}{|l|}{ Marital status } \\
\hline Single (never married) & $1020(45.5)(38.5-52.6)$ & $1.33(0.97-1.84)$ & $1.59(1.06-2.37)$ \\
\hline Married/common-law & $2040(38.2)(34.0-42.4)$ & Reference & Reference \\
\hline Widowed/divorced/separated & $560(53.8)(43.1-64.6)$ & $1.99(1.22-3.24)$ & $1.98(1.13-3.44)$ \\
\hline \multicolumn{4}{|l|}{ Region } \\
\hline Atlantic & 660 (41.8) (33.9-49.7) & $1.05(0.72-1.53)$ & $1.32(0.85-2.06)$ \\
\hline Quebec & 460 (39.7) (30.3-49.0) & $0.95(0.58-1.55)$ & $0.97(0.53-1.76)$ \\
\hline Central/Ontario & $1500(40.1)(34.8-45.4)$ & Reference & Reference \\
\hline Western & $1020(47.2)(40.0-54.4)$ & $1.35(0.94-1.94)$ & $1.28(0.86-1.91)$ \\
\hline \multicolumn{4}{|l|}{ Rank category } \\
\hline Junior noncommissioned member & $2000(44.4)(39.0-49.9)$ & Reference & Reference \\
\hline Senior noncommissioned member & $840(42.9)(36.8-49.0)$ & $0.95(0.67-1.35)$ & $0.74(0.48-1.14)$ \\
\hline Officer & $780(35.5)(30.0-40.9)$ & $0.68(0.49-0.95)$ & $0.77(0.53-1.12)$ \\
\hline \multicolumn{4}{|l|}{ Element } \\
\hline Army & $1780(45.2)(39.9-50.5)$ & Reference & Reference \\
\hline Navy & $540(35.5)(27.8-43.3)$ & $0.66(0.45-0.98)$ & $0.73(0.46-1.16)$ \\
\hline Air Force & $1300(40.6)(34.9-46.3)$ & $0.82(0.59-1.12)$ & $0.88(0.61-1.27)$ \\
\hline \multicolumn{4}{|l|}{ Ever deployed } \\
\hline No & 1520 (35.3) (24.3-46.4) & Reference & Reference \\
\hline Yes & $2100(48.4)(43.8-52.9)$ & $1.74(1.29-2.36)$ & $1.20(0.83-1.72)$ \\
\hline \multicolumn{4}{|l|}{ Lifetime sexual trauma category } \\
\hline No lifetime sexual trauma & $1580(30.3)(26.1-34.4)$ & Reference & Reference \\
\hline $\begin{array}{l}\text { Lifetime non-military-related } \\
\text { sexual assault only }\end{array}$ & 1120 (54.9) (47.6-62.2) & $2.82(1.91-4.16)$ & $1.87(1.23-2.85)$ \\
\hline $\begin{array}{l}\text { Lifetime military-related sexual } \\
\text { assault ( } \pm \text { non-military-related } \\
\text { sexual assault) }\end{array}$ & $900(66.2)(58.3-74.1)$ & $4.63(3.12-6.89)$ & $2.88(1.85-4.50)$ \\
\hline \multicolumn{4}{|l|}{$\begin{array}{l}\text { Count of types of lifetime nonsexual } \\
\text { trauma, mean }(95 \% \mathrm{Cl})\end{array}$} \\
\hline All respondents & $2.97(2.77-3.16)$ & $1.33(1.25-1.41)$ & $1.22(1.14-1.31)$ \\
\hline $\begin{array}{l}\text { Respondents without any lifetime } \\
\text { mood or anxiety disorder }\end{array}$ & $2.13(1.94-2.32)$ & & \\
\hline $\begin{array}{l}\text { Respondents with any lifetime } \\
\text { mood or anxiety disorder }\end{array}$ & $4.13(3.88-4.47)$ & & \\
\hline \multicolumn{4}{|c|}{$\begin{array}{l}\text { Note: } \mathrm{Cl}=\text { confidence interval, } \mathrm{OR}=\text { odds ratio. } \\
\text { *Any of posttraumatic stress disorder, major depression, panic disorder or generalized anxiety disorder. } \\
\text { †Binary logistic regression. } \\
\text { †Cases representing } 3.4 \% \text { of the population were excluded from the final model because of missing values. } \\
\text { \$Weighted to the entire Canadian Regular Force in service in September 2012. To protect the identity of respondents, Statistics Canada permits the } \\
\text { release only of weighted cell counts, which must be rounded to the nearest 20. We calculated prevalence rates using these rounded cell counts. } \\
\text { qExcept where noted otherwise. } \\
\text { **Adjusted for age group, marital status, region, rank category, element, deployment history and number of lifetime nonsexual traumatic events. } \\
\dagger † \text { Not included in final model owing to the lack of an unadjusted association with the outcome. }\end{array}$} \\
\hline
\end{tabular}




\begin{tabular}{|c|c|c|c|}
\hline Variable & $\begin{array}{l}\text { Weighted no. } \neq(\%) \text { of } \\
\text { participants }(95 \% \mathrm{Cl}) \S \\
n \text { in final model }=8580\end{array}$ & $\begin{array}{l}\text { Unadjusted OR } \\
\qquad(95 \% \mathrm{Cl})\end{array}$ & $\begin{array}{l}\text { Adjusted ORף } \\
\qquad(95 \% \mathrm{Cl})\end{array}$ \\
\hline \multicolumn{4}{|l|}{ Age group, yr } \\
\hline$<30$ & 460 (17.8) (12.2-23.4) & Reference & Reference \\
\hline $30-39$ & 740 (26.1) (20.7-31.4) & $1.65(1.00-2.70)$ & $1.51(0.84-2.69)$ \\
\hline$\geq 40 \mathrm{yr}$ & 560 (17.5) (13.3-21.7) & $0.99(0.61-1.61)$ & $0.76(0.39-1.49)$ \\
\hline \multicolumn{4}{|l|}{ Ethnicity } \\
\hline White & 1600 (20.9) (17.9-24.0) & Reference & $-{ }^{* *}$ \\
\hline Other & $160(17.0)(8.8-25.3)$ & $0.81(0.42-1.54)$ & $-{ }^{* *}$ \\
\hline \multicolumn{4}{|l|}{ Marital status } \\
\hline Single (never married) & $540(24.3)(18.1-30.6)$ & $1.57(1.06-2.34)$ & $1.53(0.96-2.44)$ \\
\hline Married/common-law & 920 (17.2) (13.9-20.5) & Reference & Reference \\
\hline Widowed/divorced/separated & $320(30.8)(20.8-40.7)$ & $2.14(1.25-3.65)$ & $2.44(1.33-4.50)$ \\
\hline \multicolumn{4}{|l|}{ Region } \\
\hline Atlantic & 340 (21.5) (14.7-28.3) & $1.34(0.83-2.17)$ & $1.60(0.92-2.79)$ \\
\hline Quebec & $240(20.3)(12.6-28.0)$ & $1.30(0.70-2.39)$ & $1.19(0.58-2.44)$ \\
\hline Central/Ontario & 620 (16.7) (12.5-20.8) & Reference & Reference \\
\hline Western & $580(27.1)(20.8-33.4)$ & $1.84(1.17-2.88)$ & $1.59(0.98-2.59)$ \\
\hline \multicolumn{4}{|l|}{ Rank category } \\
\hline Junior noncommissioned member & $1000(22.4)(17.8-27.1)$ & Reference & Reference \\
\hline Senior noncommissioned member & 400 (20.6) (15.5-25.7) & $0.90(0.59-1.37)$ & $0.90(0.53-1.53)$ \\
\hline Officer & $360(16.4)(12.1-20.6)$ & $0.68(0.45-1.02)$ & $0.78(0.49-1.22)$ \\
\hline \multicolumn{4}{|l|}{ Element } \\
\hline Army & $900(23.1)(18.5-27.6)$ & Reference & Reference \\
\hline Navy & $320(21.3)(14.4-28.3)$ & $0.92(0.57-1.50)$ & $1.01(0.58-1.78)$ \\
\hline Air Force & 560 (17.6) (13.3-22.0) & $0.70(0.46-1.06)$ & $0.80(0.50-1.29)$ \\
\hline \multicolumn{4}{|l|}{ Ever deployed } \\
\hline No & 700 (16.1) (12.1-20.2) & Reference & Reference \\
\hline Yes & $1080(25.4)(21.3-29.4)$ & $1.74(1.18-2.58)$ & $1.52(0.93-2.68)$ \\
\hline \multicolumn{4}{|l|}{ Lifetime sexual trauma category } \\
\hline No lifetime sexual trauma & 1580 (30.3) (26.1-34.4) & Reference & Reference \\
\hline $\begin{array}{l}\text { Non-military-related sexual assault } \\
\text { only }\end{array}$ & 1120 (54.9) (47.6-62.2) & $2.06(1.30-3.27)$ & $1.58(0.93-2.68)$ \\
\hline $\begin{array}{l}\text { Military-related sexual assault } \\
\text { ( } \pm \text { non-military-related sexual } \\
\text { assault) }\end{array}$ & $900(66.2)(58.3-74.1)$ & $4.46(2.90-6.86)$ & $3.00(1.79-5.05)$ \\
\hline \multicolumn{4}{|l|}{$\begin{array}{l}\text { Count of types of lifetime nonsexual } \\
\text { trauma, mean }(95 \% \mathrm{Cl})\end{array}$} \\
\hline All respondents & $2.95(2.76-3.15)$ & $1.23(1.15-1.31)$ & $1.15(1.07-1.24)$ \\
\hline $\begin{array}{l}\text { Respondents without any past-year } \\
\text { mood or anxiety disorder }\end{array}$ & $2.59(2.39-2.78)$ & & \\
\hline $\begin{array}{l}\text { Respondents with any past-year } \\
\text { mood or anxiety disorder }\end{array}$ & $4.37(3.84-4.89)$ & & \\
\hline \multicolumn{4}{|c|}{$\begin{array}{l}\text { Note: } \mathrm{Cl}=\text { confidence interval, } \mathrm{OR}=\text { odds ratio. } \\
\text { *Binary logistic regression. } \\
\text { tCases representing } 3.8 \% \text { of the population were excluded from the final model because of missing values. } \\
\text { fWeighted to the entire Canadian Regular Force in service in September 2012. To protect the identity of respondents, Statistics Canada permits the } \\
\text { release only of weighted cell counts, which must be rounded to the nearest } 20 \text {. We calculated prevalence rates using these rounded cell counts. } \\
\text { \$Except where noted otherwise. } \\
\text { TAdjusted for age group, marital status, region, rank category, element, deployment history and number of lifetime nonsexual traumatic events. } \\
\text { **Not included in final model owing to the lack of an unadjusted association with the outcome. }\end{array}$} \\
\hline
\end{tabular}


Table 9: Association of lifetime sexual assault with lifetime PTSD among women* $\dagger$

\begin{tabular}{|c|c|c|c|}
\hline Variable & $\begin{array}{l}\text { Weighted no. } \neq(\%) \text { of } \\
\text { participants }(95 \% \mathrm{Cl}) \S \\
n \text { in final model }=8660\end{array}$ & $\begin{array}{l}\text { Unadjusted OR } \\
\qquad(95 \% \mathrm{Cl})\end{array}$ & $\begin{array}{l}\text { Adjusted ORף } \\
\qquad(95 \% \mathrm{Cl})\end{array}$ \\
\hline \multicolumn{4}{|l|}{ Age group, yr } \\
\hline$<30 \mathrm{yr}$ & 380 (14.6) (9.5-19.7) & Reference & Reference \\
\hline 30-39 & $580(20.4)(15.4-25.4)$ & $1.53(0.90-2.62)$ & $1.49(0.78-2.83)$ \\
\hline$\geq 40$ & $680(21.0)(16.4-25.6)$ & $1.62(0.96-2.72)$ & $1.42(0.70-2.91)$ \\
\hline \multicolumn{4}{|l|}{ Ethnicity } \\
\hline White & $1440(18.7)(15.7-21.6)$ & Reference & $-{ }^{* *}$ \\
\hline Other & $200(21.3)(12.5-30.0)$ & $1.19(0.69-2.07)$ & $-{ }^{* *}$ \\
\hline \multicolumn{4}{|l|}{ Marital status } \\
\hline Single (never married) & $520(23.2)(17.0-29.5)$ & $1.60(1.04-2.45)$ & $1.68(0.95-2.95)$ \\
\hline Married/common-law & 860 (15.9) (12.7-19.1) & Reference & Reference \\
\hline Widowed/divorced/separated & $260(25.5)(15.9-35.1)$ & $1.77(1.01-3.11)$ & $2.01(1.00-4.04)$ \\
\hline \multicolumn{4}{|l|}{ Region } \\
\hline Atlantic & 220 (13.9) (8.6-19.2) & $0.63(0.37-1.08)$ & $0.69(0.37-1.31)$ \\
\hline Quebec & $160(13.6)(7.1-20.0)$ & $0.67(0.35-1.28)$ & $0.54(0.25-1.21)$ \\
\hline Central/Ontario & 760 (20.2) (15.7-24.7) & Reference & Reference \\
\hline Western & 480 (22.2) (16.0-28.4) & $1.16(0.73-1.82)$ & $0.99(0.56-1.74)$ \\
\hline \multicolumn{4}{|l|}{ Rank category } \\
\hline Junior noncommissioned member & 1000 (22.3) (17.7-27.0) & Reference & Reference \\
\hline Senior noncommissioned member & $400(20.2)(15.2-25.2)$ & $0.91(0.59-1.41)$ & $0.81(0.45-1.45)$ \\
\hline Officer & $240(10.8)(7.4-14.2)$ & $0.41(0.26-0.65)$ & $0.51(0.29-0.90)$ \\
\hline \multicolumn{4}{|l|}{ Element } \\
\hline Army & $820(20.7)(16.2-25.2)$ & Reference & Reference \\
\hline Navy & 220 (14.5) (8.7-20.2) & $0.64(0.36-1.13)$ & $0.86(0.43-1.32)$ \\
\hline Air Force & $600(18.6)(14.1-23.2)$ & $0.85(0.55-1.31)$ & $0.94(0.57-1.56)$ \\
\hline \multicolumn{4}{|l|}{ Ever deployed } \\
\hline No & 720 (16.5) (12.3-20.7) & Reference & Reference \\
\hline Yes & $920(21.3)(17.6-25.0)$ & $1.38(0.93-2.04)$ & $0.80(0.49-1.32)$ \\
\hline \multicolumn{4}{|l|}{ Lifetime sexual trauma category } \\
\hline No lifetime sexual trauma & 1580 (30.3) (26.1-34.4) & Reference & Reference \\
\hline $\begin{array}{l}\text { Non-military-related sexual assault } \\
\text { only }\end{array}$ & 1120 (54.9) (47.6-62.2) & $5.62(3.46-9.13)$ & $3.68(2.14-6.34)$ \\
\hline $\begin{array}{l}\text { Military-related sexual assault } \\
\text { ( } \pm \text { non-military-related sexual } \\
\text { assault) }\end{array}$ & 900 (66.2) (58.3-74.1) & $7.74(4.75-12.60)$ & $4.32(2.27-8.2)$ \\
\hline \multicolumn{4}{|l|}{$\begin{array}{l}\text { Count of types of lifetime nonsexual } \\
\text { trauma, mean }(95 \% \mathrm{Cl})\end{array}$} \\
\hline All respondents & $2.95(2.76-3.14)$ & $1.42(1.32-1.52)$ & $1.32(1.21-1.44)$ \\
\hline $\begin{array}{l}\text { Respondents without any lifetime } \\
\text { PTSD }\end{array}$ & $2.40(2.21-2.57)$ & & \\
\hline $\begin{array}{l}\text { Respondents with any lifetime } \\
\text { PTSD }\end{array}$ & $5.33(4.79-5.87)$ & & \\
\hline \multicolumn{4}{|c|}{$\begin{array}{l}\text { Note: } \mathrm{Cl}=\text { confidence interval, } \mathrm{OR}=\text { odds ratio, PTSD = posttraumatic stress disorder. } \\
{ }^{*} \mathrm{Binary} \text { logistic regression. } \\
\text { †Cases representing } 2.9 \% \text { of the population were excluded from the final model because of missing values. } \\
\text { †Weighted to the entire Canadian Regular Force in service in September } 2012 \text {. To protect the identity of respondents, Statistics Canada permits the } \\
\text { release only of weighted cell counts, which must be rounded to the nearest } 20 \text {. We calculated prevalence rates using these rounded cell counts. } \\
\text { §Except where noted otherwise. } \\
\text { ๆAdjusted for age group, marital status, region, rank category, element, deployment history and number of lifetime nonsexual traumatic events. } \\
{ }^{*} \text { Not included in final model owing to the lack of an unadjusted association with the outcome. }\end{array}$} \\
\hline
\end{tabular}




\section{Table 10: Association of lifetime sexual assault with past-year PTSD among women* $†$}

\begin{tabular}{|c|c|c|c|}
\hline Variable & $\begin{array}{l}\text { Weighted no. } \ddagger(\%) \text { of } \\
\text { participants }(95 \% \mathrm{Cl}) \S \\
n \text { in final model }=8700\end{array}$ & $\begin{array}{l}\text { Unadjusted OR } \\
\qquad(95 \% \mathrm{Cl})\end{array}$ & $\begin{array}{l}\text { Adjusted ORI } \\
\quad(95 \% \mathrm{Cl})\end{array}$ \\
\hline \multicolumn{4}{|l|}{ Age group, yr } \\
\hline$<30$ & $200(7.7)(3.5-11.9)$ & Reference & Reference \\
\hline 30-39 & $320(11.2)(7.2-15.1)$ & $1.55(0.73-3.29)$ & $1.48(0.61-3.57)$ \\
\hline$\geq 40$ & $240(7.4)(4.5-10.3)$ & $0.93(0.44-1.99)$ & $0.62(0.24-1.59)$ \\
\hline \multicolumn{4}{|l|}{ Ethnicity } \\
\hline White & $680(8.8)(6.5-11.0)$ & Reference & $--^{\star *}$ \\
\hline Other & $100(10.6)(4.6-16.6)$ & $1.12(0.52-2.41)$ & $--^{* *}$ \\
\hline \multicolumn{4}{|l|}{ Marital status } \\
\hline Single (never married) & $280(12.5)(7.4-17.6)$ & $1.92(1.06-3.47)$ & $1.75(0.84-3.64)$ \\
\hline Married/common-law & $360(6.7)(4.5-8.8)$ & Reference & Reference \\
\hline Widowed/divorced/separated & $140(13.5)(5.8-21.1)$ & $1.99(0.84-4.68)$ & $2.58(0.91-7.25)$ \\
\hline \multicolumn{4}{|l|}{ Region } \\
\hline Atlantic & $100(6.3)(3.1-9.4)$ & $0.54(0.25-1.16)$ & $0.63(0.26-1.57)$ \\
\hline Quebec & $60(5.1)(1.4-8.8)$ & $0.47(0.16-1.38)$ & $0.34(0.10-1.15)$ \\
\hline Central/Ontario & $380(10.1)(6.4-13.7)$ & Reference & Reference \\
\hline Western & $240(11.2)(6.6-15.8)$ & $1.08(0.57-2.04)$ & $0.88(0.41-1.87)$ \\
\hline \multicolumn{4}{|l|}{ Rank category } \\
\hline Junior noncommissioned member & 460 (10.2) (6.7-13.7) & Reference & Reference \\
\hline Senior noncommissioned member & $180(9.1)(5.3-12.9)$ & $0.92(0.5-1.72)$ & $0.96(0.44-2.13)$ \\
\hline Officer & $120(5.4)(3.0-7.9)$ & $0.47(0.26-0.95)$ & $0.67(0.29-1.55)$ \\
\hline \multicolumn{4}{|l|}{ Element } \\
\hline Army & $420(10.7)(7.2-14.1)$ & Reference & Reference \\
\hline Navy & $100(6.6)(2.3-10.8)$ & $0.64(0.29-1.44)$ & $0.84(0.31-2.27)$ \\
\hline Air Force & $240(7.4)(4.2-10.5)$ & $0.71(0.38-1.32)$ & $0.84(0.40-1.77)$ \\
\hline \multicolumn{4}{|l|}{ Ever deployed } \\
\hline No & $300(6.8)(3.8-9.9)$ & Reference & \\
\hline Yes & 460 (10.6) (7.7-13.6) & $1.64(0.92-2.94)$ & $1.10(0.57-2.13)$ \\
\hline \multicolumn{4}{|l|}{ Lifetime sexual trauma category } \\
\hline No lifetime sexual trauma & $200(3.8)(2.0-5.5)$ & Reference & Reference \\
\hline $\begin{array}{l}\text { Non-military-related sexual assault } \\
\text { only }\end{array}$ & $240(11.7)(6.4-16.9)$ & $3.51(1.71-7.19)$ & $2.14(0.94-4.86)$ \\
\hline $\begin{array}{l}\text { Military-related sexual assault } \\
\text { ( } \pm \text { non-military-related sexual } \\
\text { assault) }\end{array}$ & $320(23.5)(15.9-31.2)$ & $7.80(4.12-14.94)$ & $4.06(1.62-10.21)$ \\
\hline \multicolumn{4}{|l|}{$\begin{array}{l}\text { Count of types of lifetime nonsexual } \\
\text { trauma, mean }(95 \% \mathrm{Cl})\end{array}$} \\
\hline All respondents & $2.95(2.76-3.15)$ & $1.39(1.28-1.52)$ & $1.31(1.17-1.47)$ \\
\hline $\begin{array}{l}\text { Respondents without any lifetime } \\
\text { PTSD }\end{array}$ & $5.98(5.11-6.84)$ & & \\
\hline $\begin{array}{l}\text { Respondents with any lifetime } \\
\text { PTSD }\end{array}$ & $2.66(2.48-2.85)$ & & \\
\hline \multicolumn{4}{|c|}{ 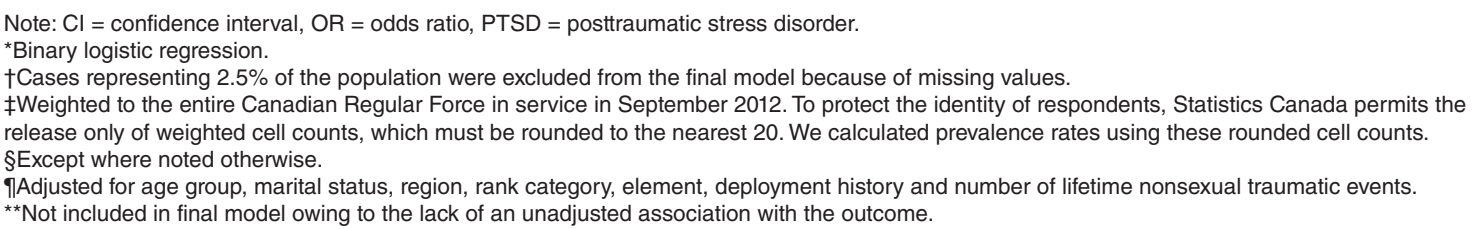 } \\
\hline
\end{tabular}


mental disorders, which may be different from those in women. ${ }^{21}$

\section{Conclusion}

Effective prevention and control of social and public health problems starts with a clear picture of the scope of the problem, the characteristics of those affected by it, the circumstances under which it occurs and its impact on the affected population. This study shows that military-related sexual assault has been reported by a sizeable fraction of Canadian military women, is associated with mental disorders and may be especially likely to occur on deployment. Although the lifetime prevalence of sexual assault among Canadian military personnel appears similar to that among other Canadians, the Canadian military may have special opportunities to address the problem, such as the recent establishment of an independent Sexual Misconduct Response Centre and initiation of prevention research, programs and policies. ${ }^{22}$ Priorities for additional research on military-related sexual assault include investigating the precise nature and circumstances of the events (and of the victims at the time of the events), which would provide additional information for prevention and control efforts.

\section{References}

1. Van Ameringen M, Mancini C, Patterson B, et al. Post-traumatic stress disorder in Canada. CNS Neurosci Ther 2008;14:171-81.

2. Farris C, Schell TL, Tanielian T. Physical and psychological bealth following military sexual assault: recommendations for care, research, and policy. Santa Monica (CA): RAND; 2013.

3. Turchik JA, Wilson SM. Sexual assault in the U.S. military: a review of the literature and recommendations for the future. Aggress Violent Behav 2010;15:267-77.

4. Williams I, Bernstein K. Military sexual trauma among U.S. female veterans. Arch Psychiatr Nurs 2011;25:138-47.

5. 2012 Workplace and gender relations survey of active duty members: tabulations of responses. Alexandria (VA): Defense Manpower Data Centre; 2013.

6. Burns B, Grindlay K, Holt K, et al. Military sexual trauma among US servicewomen during deployment: a qualitative study. Am 7 Public Health 2014;104:345-9.

7. Allard CB, Nunnink S, Gregory AM, et al. Military sexual trauma research: a proposed agenda. 7 Trauma Dissociation 2011;12:324-45.

8. Surì A, Lind L, Kashner TM, et al. Mental health, quality of life, and health functioning in women veterans: differential outcomes associated with military and civilian sexual assault. 7 Interpers Violence 2007;22:179-97.

9. Suris A, Lind L. Military sexual trauma: a review of prevalence and associated health consequences in veterans. Trauma Violence Abuse 2008;9:250-69.

10. Schell TL, Ghosh-Dastidar B. Study design and analysis approach. In: Morral $\mathrm{AR}$, Gore KL, Schell TL, editors. Sexual assault and sexual harassment in the U.S. military. Vol 2. Estimates for Department of Defense service members from the 2014 RAND Military Workplace Study. Santa Monica (CA): RAND; 2015:3-7.

11. Cotter A. Sexual misconduct in the Canadian Armed Forces, 2016. Ottawa: Statistics Canada; 2016.

12. Canadian Forces Mental Health Survey. Ottawa: Statistics Canada; 2014. Available: www23.statcan.gc.ca/imdb/p2SV.pl? Function=getSurvey \& SDDS=5084 (accessed 2015 Aug. 6)
13. World Health Organization World Mental Health Composite International Diagnostic Interview (WHO WMH-CIDI). Geneva: World Health Organization; 2004. Available: https://www.hcp.med.harvard.edu/wmhcidi/ (accessed 2016 Jan. 7).

14. Zamorski MA, Bennett RE, Boulos D, et al. The 2013 Canadian Forces Mental Health Survey: background and methods. Can f Psychiatry 2016;61(1 Suppl): 10S-25S.

15. Wilson LC. The prevalence of military sexual trauma: a meta-analysis. Trauma Violence Abuse 2016 Dec. 16 [Epub ahead of print]. doi:10.1177/524838016683459.

16. Leardmann CA, Pietrucha A, Magruder KM, et al. Combat deployment is associated with sexual harassment or sexual assault in a large, female military cohort. Womens Health Issues 2013;23:e215-23.

17. Millegan J, Milburn EK, LeardMann CA, et al. Recent sexual trauma and adverse health and occupational outcomes among U.S. service women. 7 Trauma Stress 2015;28:298-306.

18. Jaycox LH, Schell TL, Morral AR, et al. Sexual assault findings: active component. In: Morral AR, Gore KL, Schell TL, editors. Sexual assault and sexual harassment in the U.S. military. Vol 2. Estimates for Department of Defense service members from the 2014 RAND Military Workplace Study. Santa Monica (CA): RAND; 2015:9-30.

19. Kelly UA, Skelton K, Patel M, et al. More than military sexual trauma: interpersonal violence, PTSD, and mental health in women veterans. Res Nurs Health 2011;34:457-67.

20. Sadler AG, Booth BM, Cook BL, et al. Factors associated with women's risk of rape in the military environment [published erratum in Am 7 Ind Med 2003;44: 110]. Am F Ind Med 2003;43:262-73.

21. Hoyt T, Klosterman Rielage J, Williams LF. Military sexual trauma in men: a review of reported rates. 7 Trauma Dissociation 2011;12:244-60.

22. Operation HONOUR. Ottawa: National Defence and Canadian Armed Forces; 2016. Available: www.forces.gc.ca/en/caf-community-support-services/ sexual-misconduct.page (accessed 2017 Jan. 26).

Affiliation: Department of National Defence, Ottawa, Ont.

Contributors: Kimberley Watkins wrote and revised most of the manuscript. Rachel Bennett conducted the statistical analyses, prepared the tables and contributed to the writing of the Methods section. Mark Zamorski contributed substantially to the study design and implementation, data analysis and interpretation, and writing and revising the manuscript. Isabelle Richer contributed to the design of the statistical analyses and the writing of the abstract. All of the authors approved the final version to be published and agreed to act as guarantors of the work.

Funding: The Department of National Defence provided the authors' salaries and funded the survey development and administration.

Role of funders: The investigators developed the study protocol, which was accepted by the study sponsor without modification. The sponsor had no direct role in data collection or analysis. In accordance with Department of National Defence (DND) policy, the paper was reviewed and approved for submission without modification by Defence Research and Development Canada and the Canadian Armed Forces Deputy Surgeon General. No undue influence on the part of DND, the Canadian Armed Forces or the Government of Canada occurred at any part of this research project.

Disclaimer: The opinions expressed or implied in this publication are those of the authors and do not represent the views or policy of the Department of National Defence or the Canadian Armed Forces.

Supplemental information: For reviewer comments and the original submission of this manuscript, please see www.cmajopen.ca/content $/ 5 / 2 /$ E496/suppl/DC1 